----مجلة علوم الرافدين، المجلد 27، العدد 4 /عدد خاص بالمؤتمر العلمي الثالث لعلوم الحياة، ص258-270، 2018--

فصص حساسية عزلات جرثومة Acinetobacter baumannii والتحري عن فئة الجينات التابعة لـ

$$
\text { كلية النور الجامعة نوفل وجيه }
$$

$$
\text { (أستلم 2018/6/20 ؛ قُبل 2018/11/1) }
$$

\title{
الملخص
}

أظهرت ثــان عزلات تابعـة للنوع Acinetobacter baumannii مقاومسةً مطلقـة بنسبة 100\% لمضـادات،

Ticarcillin، Piperacillin، Gentamicin، Cefotaxime ، Ciprofloxacin، Ceftriaxone ، Ampicillin 100 Trimethoprim-sulfamethoxazol، 50\% وكانت قلبلة المقاومة للمضاد Amikacin والـ Netillin وإذبلغت نسبة المقاومة لهما (37.5\%). وبغية التحري عن أسباب المقاومة تم الكثف عن نواجد الجينات bla و 87.5\% على التوالي فيما لم يتم الكثف عن الجين Ala oxa58 في جميع عزلات A.baumannii التي أكدت مقاومتها لمضادات

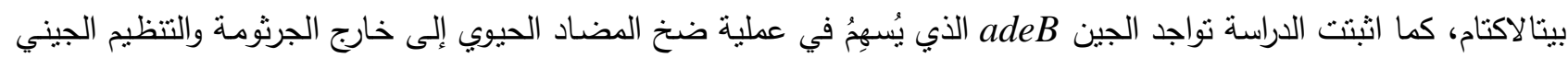
لجينات adeR و adeS التي أكد وجودها مقاومة الجرثومة للمضادات الحيوية.

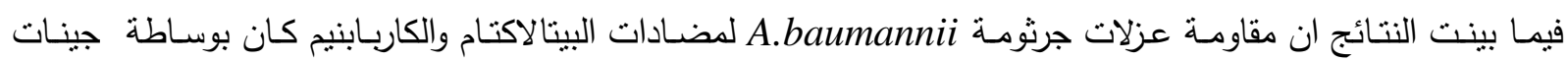

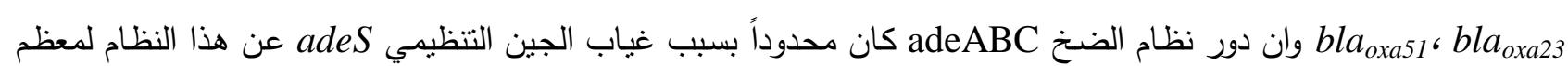

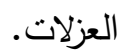
الكلمات الدالة: Adedaumannii ، AdeR ، adeB، bla

\section{Sensitivity Testing of Acinetobacter baumannii and Detection of some Resistance Genes Affiliate of $b_{l a}$ oxa and $a d e A B C$}

\author{
Dena N. Wajeeh \\ Alnoor University College
}

Adeeba Y. Shareef

Department of Biology/ College of Science/ University of Mosul

\author{
Shakeeba Y. Shareef \\ Nineveh Health Department
}

\begin{abstract}
Eight isolates of Acinetobacter baumannii showed absolute resistance (100\%) to Ampicillin, Ceftriaxone, Ciprofloxacin, Cefotaxime, Gentamicin, Piperacillin, Ticarcillin, Trimethoprimsulfamethoxazol, while it showed moderate resistance (50\%) to Tobramycin and low resistance to each of Amikacin and Netillin (37.5\%).

For the detection of the causes of resistance bla $_{\text {oxa51 } 1}$ genes, bla $_{\text {oxa53 }}$ genes were detected at a rate of $100 \%$ and $87.5 \%$ respectively, while the gene bla isolates which confirmed its resistance to B-lactam antibiotics, the results also confirms the
\end{abstract}


presence of the gene $a d e B$ which plays role in efflux pump mode of resistance as well as the regulatory genes of adeR and adeS of which their presence confirm the bacterial resistance to antibiotics.

The results showed that the resistance of A.baumannii to B-lactam and Carbapenem antibiotics were mediated by $b l a_{\text {oxa23 }}, b l a_{\text {oxa51 }}$ and the role of AdeABC was restricted due to the absence of the $A d e S$ regulatory gene from most isolates.

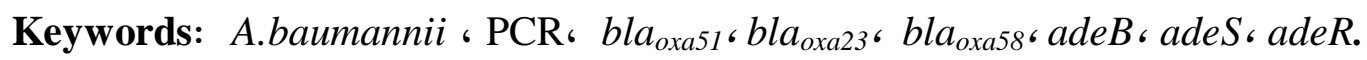

\section{المقدمة}

تعد جرثومـة Acinetobacter baumannii من الجراثيم العصوية السالبة لصبغة كرام غير المخمرة لسكر اللاكتوز والمسببة لعدوى المستشفيات ولذللك تعد من أهم أنواع جنس Acinetobacter، إذ تم عزلها من الجهاز التنفسي والجروح والدم

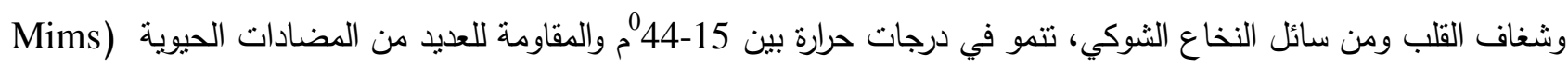
.(et al., 2004; Adams and Koch, 2010 ركزت دراسـات المقاومسة للمضـادات الحيويـة لجرثومـة A.baumannii على عدة آليات منها نفاذيـة الغشـاء الخـارجي وإنتاج أنزيمات تعمل على تتبيط فعالية المضاد الحيوي منل انزيمات A-lactamase وتغيير موقع ارتباط المضاد الحيوي بالموقع

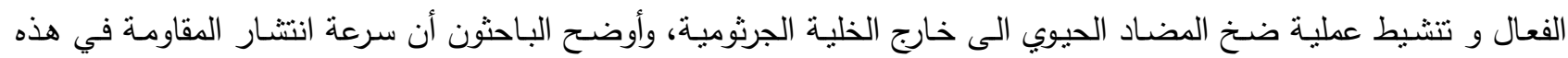
الجرثومة تتم من خلال العناصر الناقلة او من خلال حدوث الطفرات (Sun et al., 2012). وتعد مضـادات البيتا لاكتام من المضـادات واسعة الطيف حيث تعمل على توقف عملية بنـاء الجدار الخلوي للجرثومـة

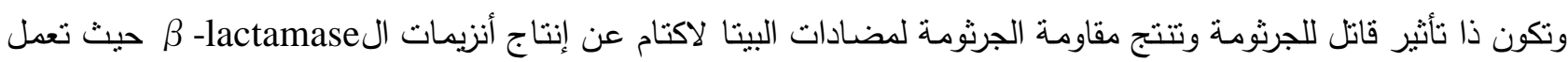

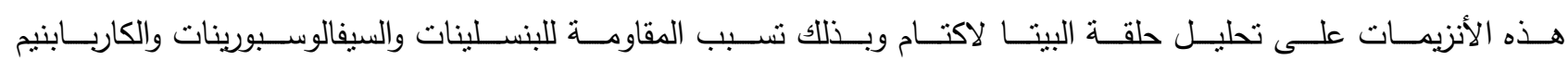

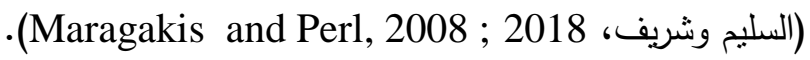
وتصنَّف مضادات الكلايكوسيدات الامينية ضمن المضادات القاتلة للجرثومـة، إذ نؤثر في بروتينات الغثـاء البلازمي من خـلا تكوين بروتينات غير طبيعيـة تتداخل ضـمن الغشـاء البلازمي، تتسبب في فقدان وظيفته وموت الجرثومـة نتيجـة تأثرها باختلاف التركيز بين داخل الخلية وخارجها (Mims et al.,2004; Adams and Koch, 2010) . في حين تتداخل مضادات السلفونمايد مـع ايض الخلية الجرثومية اذ تمنع بنـاء حامض الفولك الذي يعد من المركبات المهمة في بناء الاحماض النووية RNA و DNA وتعد هذه المضادات من مشابهات المركب Para aminobenzoic acid الذي يعد مـن المركبـات المهمـة في بنـاء حامض الفولك، وبسبب زيـادة انتشـار جين erm وغيرهـا من جينـات المقاومـة لهذهـ المضـادات تم تحوير المضـاد إلى المركب المتكون من Sulfamethaxol مـع Trimethoprim (محمود وشـريف، 2018؛

.(Pommerville, 2011

تعد عائلة RND جينات ناقلة غشائية من نوع Proton antiporters التي تنتعمل التدرج في البروتونات لتقوية الضخ، وان التبادل يكون بين أيون واحد للهيدروجين H+ لكل جزيئة منقولة، ويتكون نظام RND من adeB الذي يعد البروتين الناقل

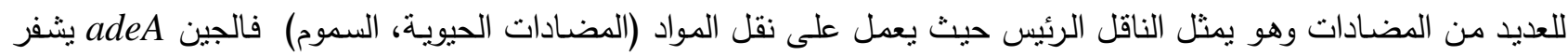
لتكوين البروتين المساعد في المسافة البينية وهو يتوسط التعابر بين المكونين AdeB و AdeC، وهو مماثل للبروتينات الغشائية adeC ويعمل على تقريب الغشائين الخارجي والداخلي ويثبت تركيب بروتينات الغشاء الخارجي (MFP)

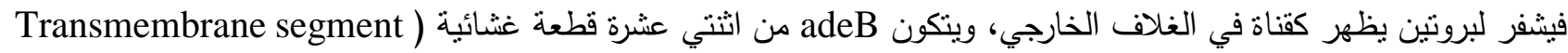


تعمل على تكوين انحناعين طويلين بين TMS1 و TMS و TMS2 وTMS7 يتم نقل المواد المختلفة خلال عملية تدرج البروتونات الكيمو كهربائية Electrochemical gradient of protons من خلص الغشاء كما هو موضح في الثكل (1) .(Paulsen, 2003; Eswaran et al., 2004)

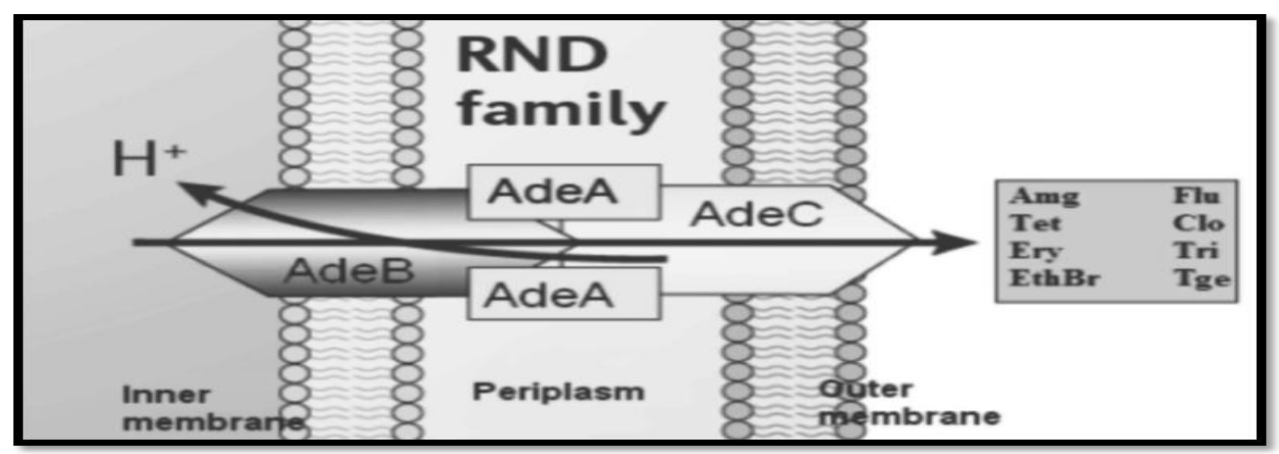

الثكل 1: موقع نظام الضخ adeABC في الخلية الجرثومية

Amg - aminoglycosides, Flu - fluoroquinolones, Tet - tetracyclines, Clo- chloramphenicol, Ery erythromycin, Tri - trimethoprim, EthBr -ethidium bromide, Tge - tigecycline. (Wieczorek et al., 2008).

وتثير التجارب التي أجراها من قبل (2004) Marchand et al., إلى وجود جين adeS يمثل أصلا لتعبير جينات adeABC فضـلا عن ذلك إثـارته إلى أن تعبير مضخات adeABC يقع تحت سبطرة مكونـات النظام الثنائي المتكون من الـ adeR و adeS، ويقع نظام الضخ ضdeABC ضمن تأثنير مؤثرات بيئية تعمل على تنشيط نظام الضخ او تثبيطه، كما ذكر ان الجينات التتظيمية adeR و adeS تعد المتحكم في تعبير نظام الضخ adeABC فتنشيط الجينات التنظيمية يسهم في زيادة تغيير نظام الضخ adeABC وبالتالي زيادة مقاومة الجرثومة للمضادات الحيوية في تتشيط جين adeS لتكوين مسار Sadensor kinase والذي يسهم في عملية التحسس واستلام الإشارة ويتحس ايـة تغيرات قد تؤثر في الخلية الجرثومية من خلال منطقة

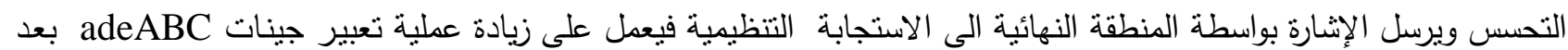
استلام الإثارة ويشفره جين adeR كما موضـح في الثنكل(2) وعملية الإرسال واستلام الإشارة المحفزة تكون خلال عملية الفسفرة

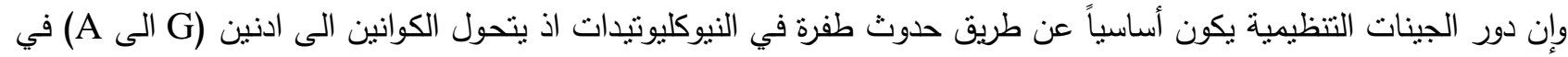
الجين adeR وهذا التحول يعمل على تحويل الحامض الاميني الاسبارنك الى الحامض الاميني الاسباراجين في حين لا يحدث • (Wieczorek et al., 2008 ;Sun et al., 2012; Zhang et al.,2018 ) adeS نغيير في الجيني

\section{ades adeR adeA} ade $B$ adec

الشكل 2: موقع جينات نظام الضخ adeABC والجينات التظيمية adeSR

(Magnet et al., 2001) هدفت الدراسة الحالية إلى: - (1) 1 - تحديد حساسية جرثومة A.baumannii إزاء مجموعة من المضادات الحيوية. 2- تحديد بعض جينات المقاومة للمضادت الحيوية. 


\section{دينا نوفل وجيه وآخرون \\ المواد وطرائق العمل}

استعملت ثماني عزلات لجرثومة A.baumannii المعزولة من مرضسى الحروق الراقدين في المستشفى والمشخصـة في

دراسة سابقة بالطرائق التقليدية واثرطة (20) API المجهز من قبل شركة Bio meriux الفرنسية على النحو الآتي:

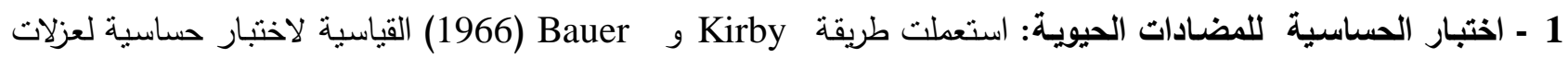
, Gentamicin, Doxycylin, Ciprofloxacin, Cefotaxime, Ceftriaxone, للمضادات الحيوية A.baumannii Ampicillin, Amikacin, Ticarcillin, Tetracycline, Trimethoprim-sulfamethoxazo, Tobramicin

.(Pommerville, 2011),Piperacillin, Netilmicin, Imipenem,

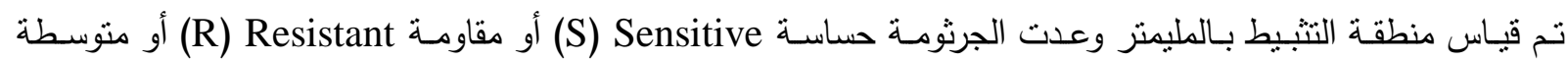
الحساسية Intermediate حسب المعدلات القياسية لقطر منطقة التثبط المناظرة للمواصفات القياسية الواردة في الثوابت المختبرية العالمية (CLSI, 2012).

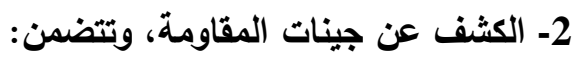
أ: استخلاص الحامض النووي الجينـي لجرثومة A.baumannii باستخدام عدة الاستخلاص التي جهزتها شركة OMEGA

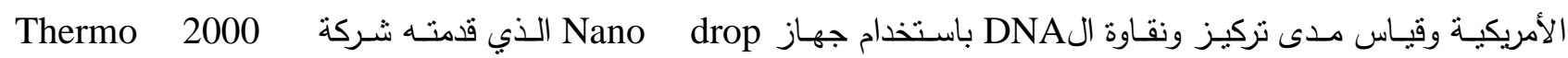
spectrophotometer ب: تفاعلات PCR: اجري التفاعل باستخدام البادئات المجهزة من قبل شركة Certifirate of analysis الأمريكية وباستعمال

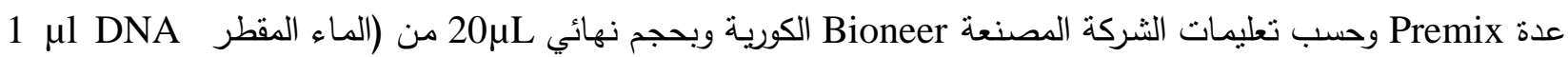
template $15 \mu 1$, Premix $2 \mu$ l, Primer reverse $1 \mu 1$, Primer forward $1 \mu 1$, adeR

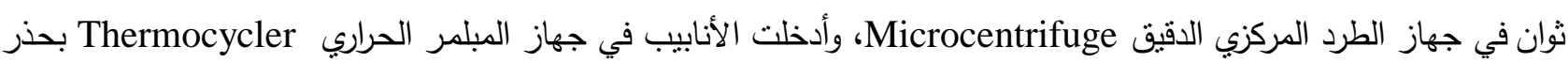
وعناية لإنجاز التفاعل بإتباع البرنامج الخاص لكل بادئ كما مبين في (الجدول1 و 2).

الجدول 1: تسلسل البوادئ المستخدمة في الدراسة

\begin{tabular}{|c|c|c|c|}
\hline 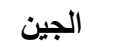 & ت ت ت ابع البادئ & 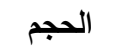 & المصدر \\
\hline bla $_{\text {oxa51 }}$ & $\begin{array}{l}\text { F : 5'-TAATGCTTTGATCGGCCTTG-3' } \\
\mathrm{R}: 5^{\prime} \text { - TGGATTGCACTTCATCTTGG-3' }\end{array}$ & $353 b p$ & (Nowak et al., 2012) \\
\hline bla $_{\text {oxa } 23}$ & 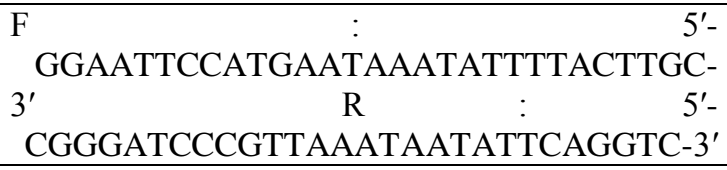 & $589 \mathrm{bp}$ & ( Mugnier et al.,2010) \\
\hline$b^{\prime} a_{\text {oxa } 58}$ & $\begin{array}{r}\mathrm{F}: \text { 5'-CGATCAGAATGTTCAAGCGC-3' }^{\prime} \\
\mathrm{R}: \text { 5'-ACGATTCTCCCCTCTGCGC-3' }^{\prime}\end{array}$ & $528 \mathrm{bp}$ & (Poirel et al., 2005; Ozen et al., 2009) \\
\hline adeB & $\begin{array}{l}\text { F: 5'-GTATGAATTGATGCTGC-'3 } \\
\text { R: 5'-CACTCGTAGCCAATACC-'3 }\end{array}$ & 979bp & (Huys et al., 2005) \\
\hline$\overline{a d e R}$ & $\begin{array}{r}\mathrm{F}: 5 \text { '-ATGTTTGATCATTCTTTTTCTTTTG-'3 } \\
\mathrm{R}: \text { 5-TTAATTAACATTTGAAATATG-'3 }\end{array}$ & $687 \mathrm{bp}$ & (Srinivasan et al., 2009) \\
\hline ades & $\begin{array}{r}\text { F }: 5 \text { 'TATGAAAAGTAAGTTAGGAAT- -'3 } \\
\mathrm{R}: 5 \text { '-TTAGTTATTCATAGAAATTTT -'3 }\end{array}$ & $1072 \mathrm{bp}$ & ( Coyne et al., 2010) \\
\hline
\end{tabular}


الجدول 2: البرامج المستخدمة لتفاعلات الـ PCR

\begin{tabular}{|c|c|c|}
\hline 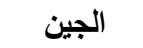 & برنامج التفاعل & 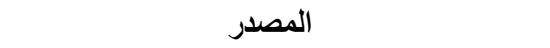 \\
\hline blaoxa51 & $\begin{array}{r}94 \mathrm{C}^{0} \text { for } 5 \mathrm{~min}, 30 \text { cycles of } 94 \mathrm{C}^{0} \text { for } 25_{\mathrm{S}}, 52 \mathrm{C}^{0} \text { for } 30_{\mathrm{S}} \\
72 \mathrm{C}^{0} \text { for } 50_{\mathrm{S}}, 72 \mathrm{C}^{0} \text { for } 6 \mathrm{~min}\end{array}$ & (Nowak et al., 2012 ) \\
\hline bla $a_{\text {oxa } 23}$ & $\begin{array}{r}95 \mathrm{C}^{0} \text { for } 10 \mathrm{~min}, 35 \text { cycles of } 95 \mathrm{C}^{0} \text { for } 1 \mathrm{~min}, 55 \mathrm{C}^{0} \text { for } 1 \mathrm{~min} \text {, } \\
68 \mathrm{C}^{0} \text { for } 2 \mathrm{~min}, 68 \mathrm{C}^{0} \text { for } 5 \mathrm{~min}\end{array}$ & ( Mugnier et al.,2010) \\
\hline bla $a_{\text {oxa } 58}$ & $\begin{array}{r}94 C^{0} \text { for } 10 \mathrm{~min}, 35 \text { cycles of } 94 C^{0} \text { for } 1 \mathrm{~min}, 55 C^{0} \text { for } 1 \mathrm{~min} \text {, } \\
72 C^{0} \text { for } 3 \mathrm{~min}, 72 C^{0} \text { for } 5 \mathrm{~min}\end{array}$ & (Poirel et al., 2005 ; Ozen et al., 2009) \\
\hline$A d e B$ & $\begin{array}{r}94 C^{0} \text { for } 5 \mathrm{~min}, 25 \text { cycles of } 94 C^{0} \text { for } 30_{S}, 55 C^{0} \text { for } 1 \mathrm{~min}, \\
72 C^{0} \text { for } 1 \mathrm{~min}, 72 C^{0} \text { for } 7 \mathrm{~min}\end{array}$ & (Huys et al., 2005) \\
\hline AdeR & $\begin{array}{r}95 C^{0} \text { for } 5 \mathrm{~min}, 30 \text { cycles of } 95 C^{0} \text { for } 30_{S}, 46 C^{0} \text { for } 1 \mathrm{~min}, \\
72 C^{0} \text { for } 1 \mathrm{~min}, 72 C^{0} \text { for } 10 \mathrm{~min}\end{array}$ & (Srinivasan et al., 2009) \\
\hline AdeS & $\begin{array}{r}95 \mathrm{C}^{0} \text { for } 3 \mathrm{~min}, 35 \text { cycles of } 95 \mathrm{C}^{0} \text { for } 1 \mathrm{~min}, 55 \mathrm{C}^{0} \text { for } 30_{\mathrm{S}} \text {, } \\
72 \mathrm{C}^{0} \text { for } 1 \mathrm{~min}, 72 \mathrm{C}^{0} \text { for } 10 \mathrm{~min}\end{array}$ & ( Coyne et al., 2010 ) \\
\hline
\end{tabular}

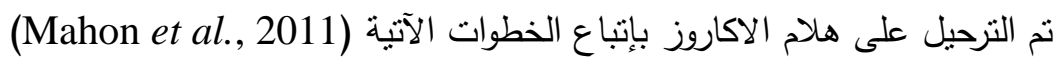
1- حضر هلام الاكاروز بتركيز 0.8\% (TBE) 15مل، الاكاروز 1.2غم، ماء مقطر 135مل) وذلك للكثف عن عينات الدنا

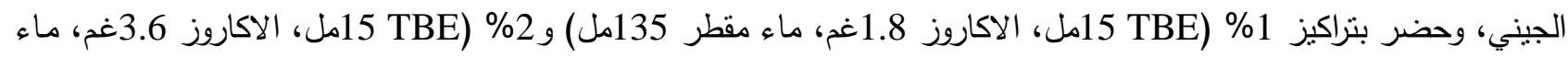

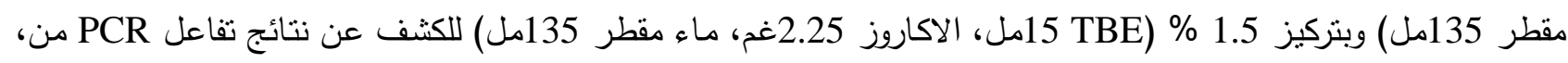
حيث تمت الإذابة بدرجة الغليان عن طريق وضعه في جهاز Microwave ثم نرك ليبرد إلى درجة حرارة 50 م. 2- - ركب قالب الهام ثم وضع المشط. 3- سكب الاكاروز في القالب، وترك الهلام الى ان يتصلب ثم رفع المشط.

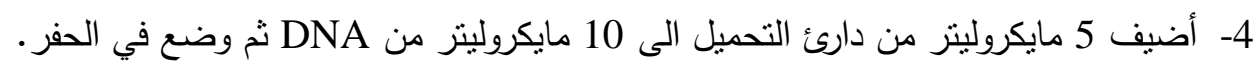

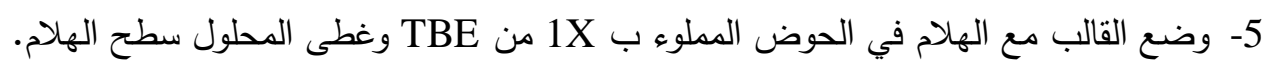

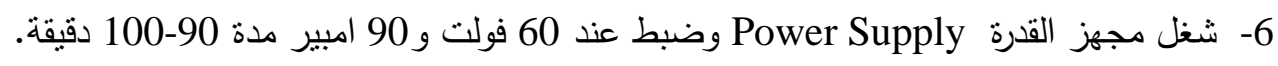
7- صبخ هلام الاكاروز بصبغة بروميد الاثيديوم لمدة تلث ساعة.

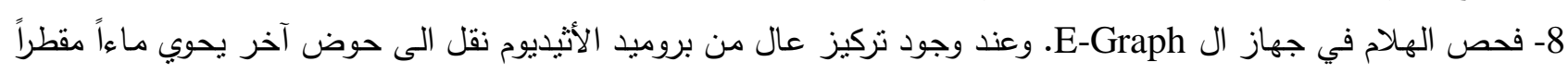
الإزالة الصبغة الزائدة.

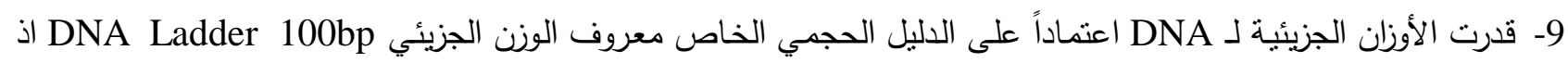
أعطى هذا الدليل في هلام الاكَاروز اثثي عشرة حزمة أو إحدى عشرة حزمة ذات أحجام جزيئية معروفة وحسب الثركة المصنعة Biolab البريطانية وشركة Promega الامريكية.

\section{النتائج و المناقشة}

أجري فحص الحساسية للمضادات الحيوية لعزلات جرثومة A. baumannii الثمانية ضد أربعة عشر نوعا من المضادات كما موضـح في الصورة (1) وللكثف عن نمط مقاومتها للمضـادات الحيويـة المستخدمة سجلت النتائج من خـلال فياس أقطار

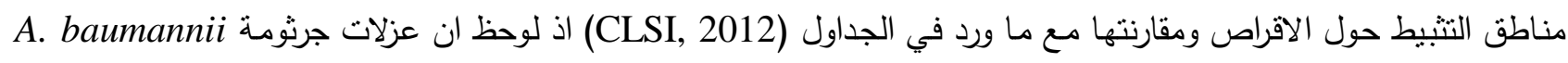

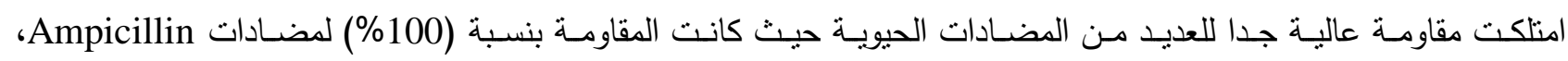
Piperacillin ،Trimethoprim-Sulfamethoxazol ،Gentamicin ،Cefotaxime ،Ciprofloxacin ،Ceftriaxone 
، كicarcillin كما موضح في (الجدول 3) فيما اختلفت مقاومة الجرثومة للمضاد الحيوي الـ Amikacin وبنسبة 37.5\% ولـ

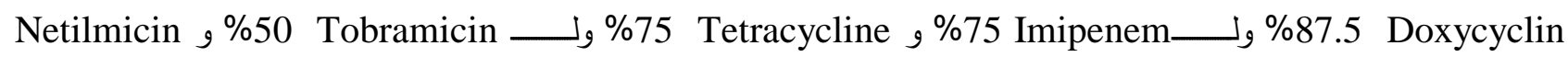

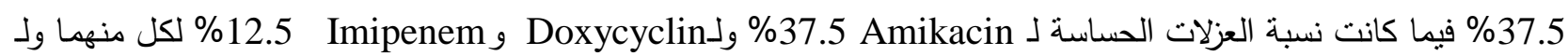

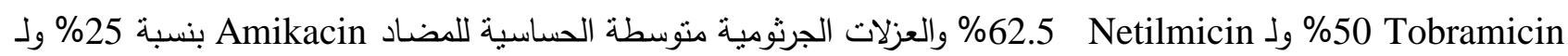
Tetracyclin و Imipenem

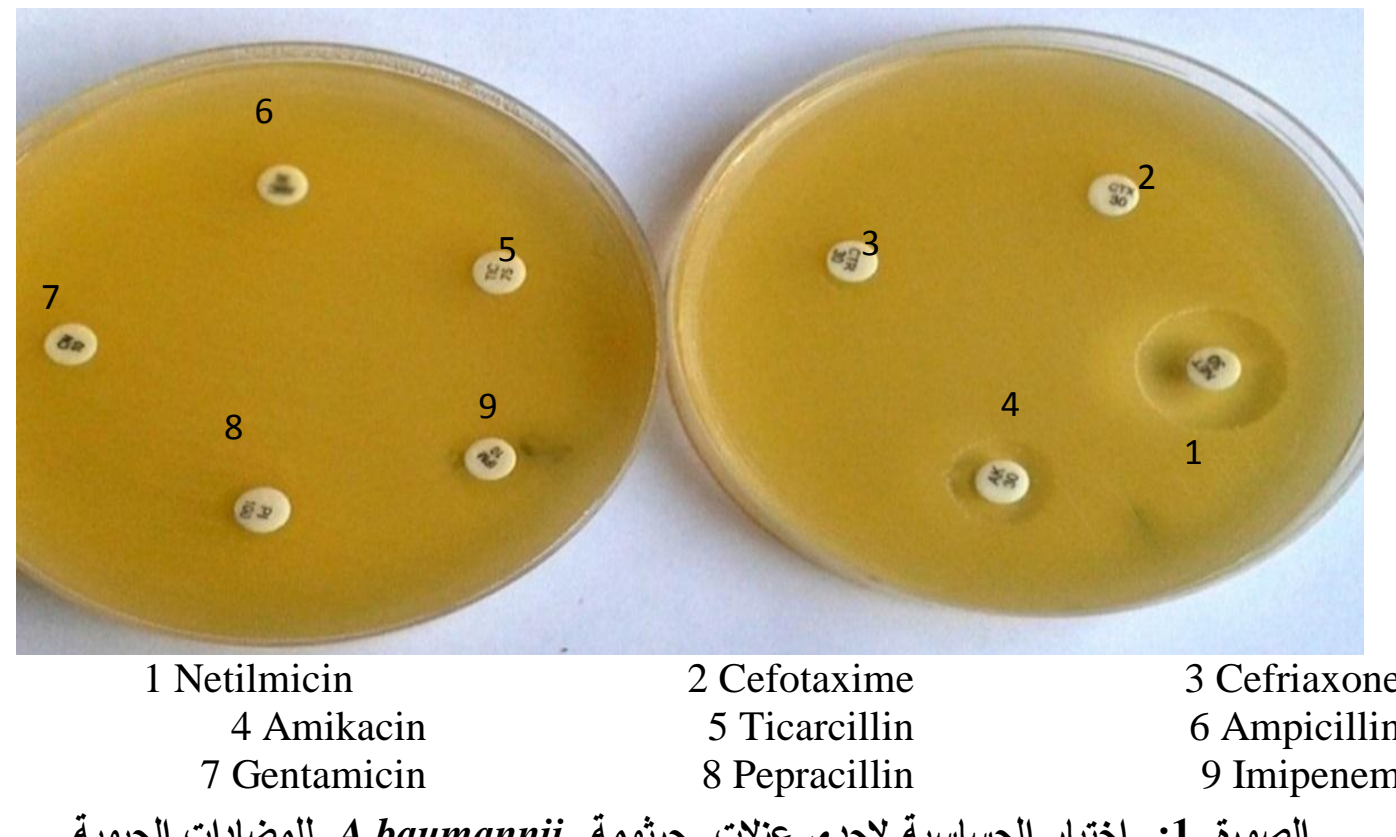

الصورة 1: اختبار الحساسية لإحدى عزلات جرثومة A.baumannii للمضادات الحيوية

الجدول 3: العزلات الجرثومية التابعة للنوع A.baumannii المقاومة والحساسة للمضادات الحيوية ونسبها المئوية

\begin{tabular}{|c|c|c|c|}
\hline العزلات المقاومة (\%) & العزلات متوسطة (\%) & العزلات الحساسة (\%) & اسم المضاد الحيوي \\
\hline$(37.5) 3$ & $(25) 2$ & $(37.5) 3$ & Amikacin \\
\hline 8 & - & - & Ampicillin \\
\hline (100) 8 & _- & _- & Ceftriaxone \\
\hline (100) 8 & _- & _- & Cefotaxime \\
\hline (100) 8 & _- & _- & Ciprofloxacin \\
\hline (87.5) 7 & _- & (12.5) 1 & Doxycyclin \\
\hline (100) 8 & - & - & Gentamicin \\
\hline (75) 6 & $(12.5) 1$ & $(12.5) 1$ & Imipenem \\
\hline (100) 8 & _ & _ & Piperacillin \\
\hline (75) 6 & (12.5) 1 & (12.5) 1 & Tetracycline \\
\hline (100) 8 & - & - & Ticarcillin \\
\hline (100) 8 & - & - & $\begin{array}{c}\text { Trimethoprim- } \\
\text { sulfamethoxazol }\end{array}$ \\
\hline (50) 4 & _ & (50) 4 & Tobramicin \\
\hline (37.5) 3 & _- & (62.5) 5 & Netilmicin \\
\hline
\end{tabular}


وبينت نتائج تفاعل الـ PCR للجين Pla

الصورة (2)، وأما بالنسبة للجين bla oxa23 فأظهرت النتائج تواجده في جميع العزلات الجرثومية ما عدا العزلة الجرثومية رقم أربعة اذ لم يظهر الجين على الرغم من المحاولات المتكررة كما موضح في الصورة (3)، وعدم تواجد الجين

العزلات الجرثومية على الرغم من المحاولات المتكررة لتفاعل الـ PCR كما موضح في الصورة (4):

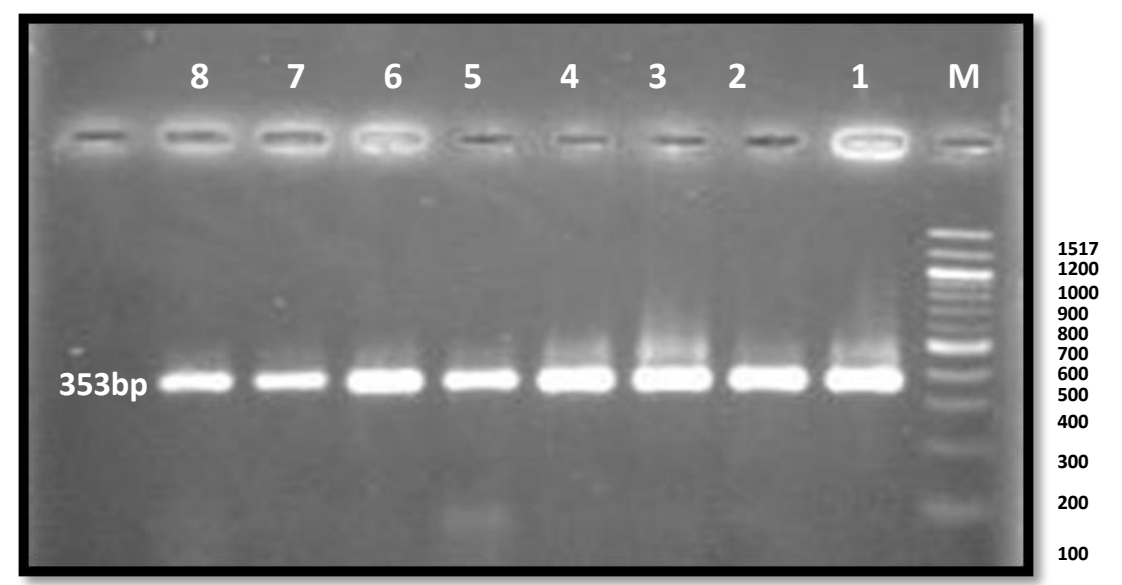

الصورة 2 : نتائج تضاعف DNA لعزلات جرثومة A.baumannii باستخدام تقنية PCR لجين bla

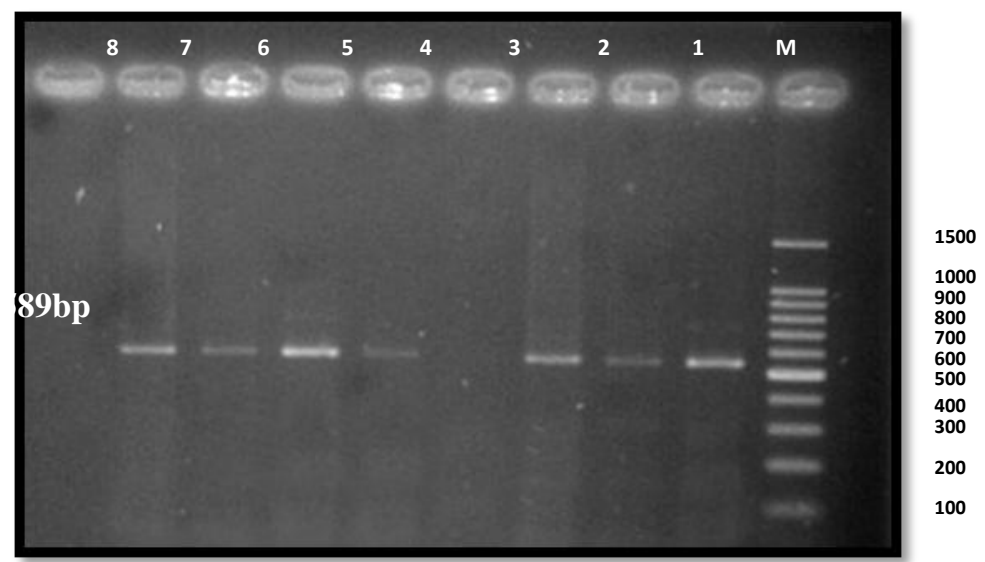

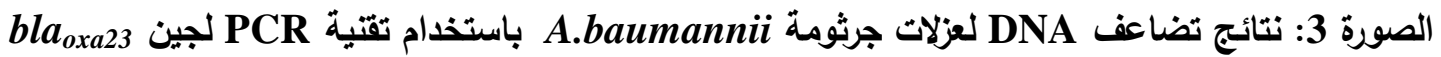

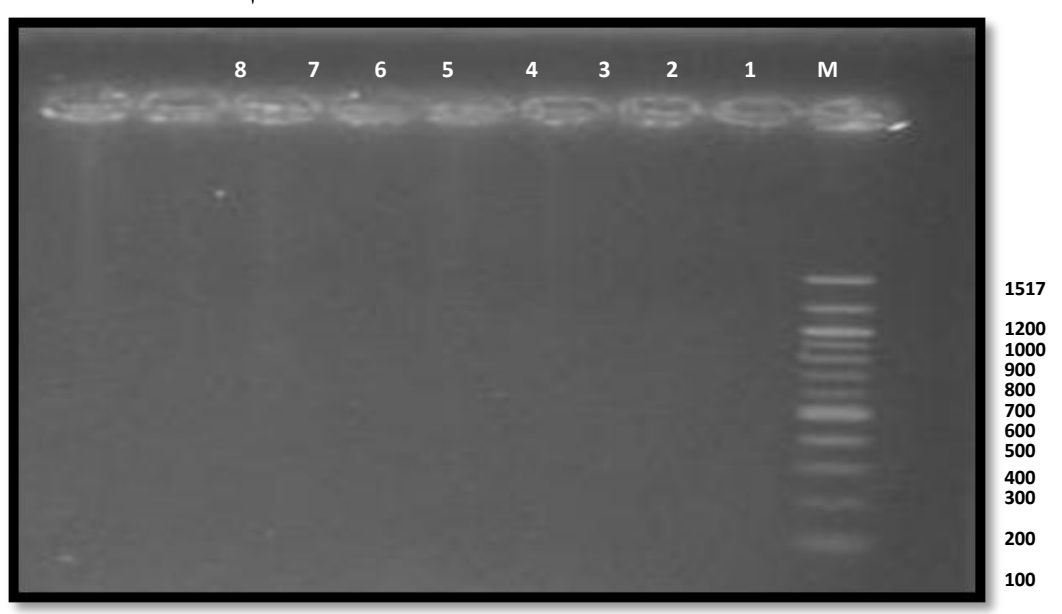

الصورة 4: نتائج تضاعف DNA لعزلات جرثومة A.baumannii باستخدام تقنية PCR لجين bla 
عند مقارنة نتائج اختبار تفاعل الـ PCR واختبار فحص الحساسية ظهرت العزلات الجرثومية التي امتلكت الجين

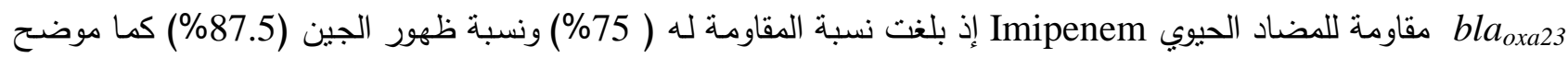
في الصورة (3) و (الجدول 4)، أما العزلة رقم 4 فقد كانت حساسة للمضاد Imipenem، وفيما يتعلق بالجين bla النتائج عدم امتلاك أية عزلة من العزلات الثمانية لهذا الجين على الرغم من تطبيق اكثر من برنامج لتفاعل PCR لهذا الجين، إن ظهـور جينـات bla oxa51 وbla oxa المضادات الحاوية على حلقة البيتالاكتام (Mahon et al., 2011). الجـدول 4: العلاقــة بـين الجينـات blaoxa51 و blaoxa32 و عزلات جرثومة A.baumannii للمضادات الحيوية

\begin{tabular}{|c|c|c|c|c|c|c|c|c|}
\hline 8 & 7 & 6 & 5 & 4 & 3 & 2 & 1 & العزلات \\
\hline $\mathrm{R}$ & $\mathrm{R}$ & $\mathrm{R}$ & $\mathrm{R}$ & $\mathrm{R}$ & $\mathrm{R}$ & $\mathrm{R}$ & $\mathrm{R}$ & Ticarcillin \\
\hline $\mathrm{R}$ & $\mathrm{R}$ & $S$ & $\mathrm{R}$ & $\mathrm{S}$ & $S$ & $\mathrm{R}$ & $\mathrm{S}$ & Tobramycin \\
\hline $\mathrm{R}$ & $\mathrm{R}$ & $\mathrm{R}$ & $\mathrm{R}$ & $\mathrm{R}$ & $\mathrm{I}$ & $\mathrm{R}$ & $\mathrm{S}$ & Tetracycline \\
\hline $\mathrm{R}$ & $\mathrm{S}$ & $\mathrm{S}$ & $\mathrm{R}$ & $\mathrm{S}$ & $\mathrm{S}$ & $\mathrm{R}$ & $\mathrm{S}$ & Netilimicin \\
\hline $\mathrm{R}$ & $\mathrm{R}$ & $\mathrm{R}$ & $\mathrm{R}$ & $\mathrm{R}$ & $\mathrm{R}$ & $\mathrm{R}$ & $\mathrm{R}$ & Piperacillin \\
\hline $\mathrm{I}$ & $\mathrm{R}$ & $\mathrm{R}$ & $\mathrm{R}$ & $\mathrm{S}$ & $\mathrm{R}$ & $\mathrm{R}$ & $\mathrm{R}$ & Imipenem \\
\hline$\overline{\mathrm{R}}$ & $\mathrm{R}$ & $\mathrm{R}$ & $\mathrm{R}$ & $\mathrm{R}$ & $\mathrm{R}$ & $\mathrm{R}$ & $\mathrm{R}$ & Gentamicin \\
\hline $\mathrm{R}$ & $\mathrm{R}$ & $\mathrm{S}$ & $\mathrm{R}$ & $\mathrm{R}$ & $\mathrm{R}$ & $\mathrm{R}$ & $\mathrm{R}$ & Doxycyclin \\
\hline $\mathrm{R}$ & $\mathrm{R}$ & $\mathrm{R}$ & $\mathrm{R}$ & $\mathrm{R}$ & $\mathrm{R}$ & $\mathrm{R}$ & $\mathrm{R}$ & Ciprofloxacin \\
\hline $\mathrm{R}$ & $\mathrm{R}$ & $\mathrm{R}$ & $\mathrm{R}$ & $\mathrm{R}$ & $\mathrm{R}$ & $\mathrm{R}$ & $\mathrm{R}$ & Cefotaxime \\
\hline $\mathrm{R}$ & $\mathrm{R}$ & $\mathrm{R}$ & $\mathrm{R}$ & $\mathrm{R}$ & $\mathrm{R}$ & $\mathrm{R}$ & $\mathrm{R}$ & Ceftriaxone \\
\hline $\mathrm{R}$ & $\mathrm{R}$ & $\mathrm{R}$ & $\mathrm{R}$ & $\mathrm{R}$ & $\mathrm{R}$ & $\mathrm{R}$ & $\mathrm{R}$ & Ampicillin \\
\hline $\mathrm{R}$ & $\mathrm{I}$ & $\mathrm{I}$ & $\mathrm{R}$ & $\mathrm{S}$ & $\mathrm{S}$ & $\mathrm{R}$ & $\mathrm{S}$ & Amikacin \\
\hline+ & - & - & - & - & - & - & - & AdeS \\
\hline+ & + & + & + & + & + & + & + & AdeR \\
\hline+ & + & + & - & + & + & + & - & AdeB \\
\hline- & - & - & - & - & - & - & - & $b^{b l a} a_{O x a 58}$ \\
\hline+ & + & + & + & - & + & + & + & bla $_{\text {Oxa } 23}$ \\
\hline+ & + & + & + & + & + & + & + & bla $_{\text {Oxa } 51}$ \\
\hline
\end{tabular}

رموز الثكل: ظهور الجين (+) عدم ظهور الجين (-) مقاومة (R) مساسة (S) (I) معتلة الحساسية(I)

كما بينت نتائج الدراسـة عدم ظهور الجين adeB في العزلات الجرثومية الأولى والخامسة وظهوره في باقي العزلات كما موضح في الصورة (5)، والصورة (6) بينت ظهور الجين adeR في جميع العزلات الجرثومية اما بالنسبة للجين adeS فقد لوحظ وجوده في العزلة الجرثومية الثامنة فقط وعدم ظهوره في باقي العزلات الجرثومية كما في الصورة (7). 


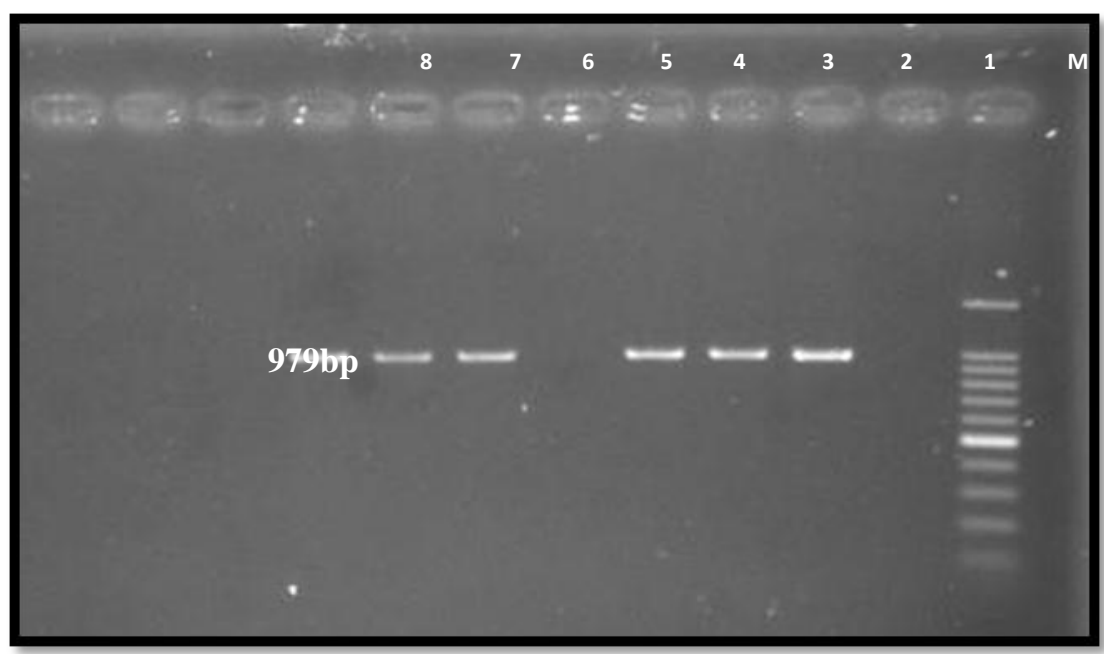

الصورة 5: نتائج تضاعف DNA لعزلات جرثومة A.baumannii باستخدام تقتية PCR لجين adeB

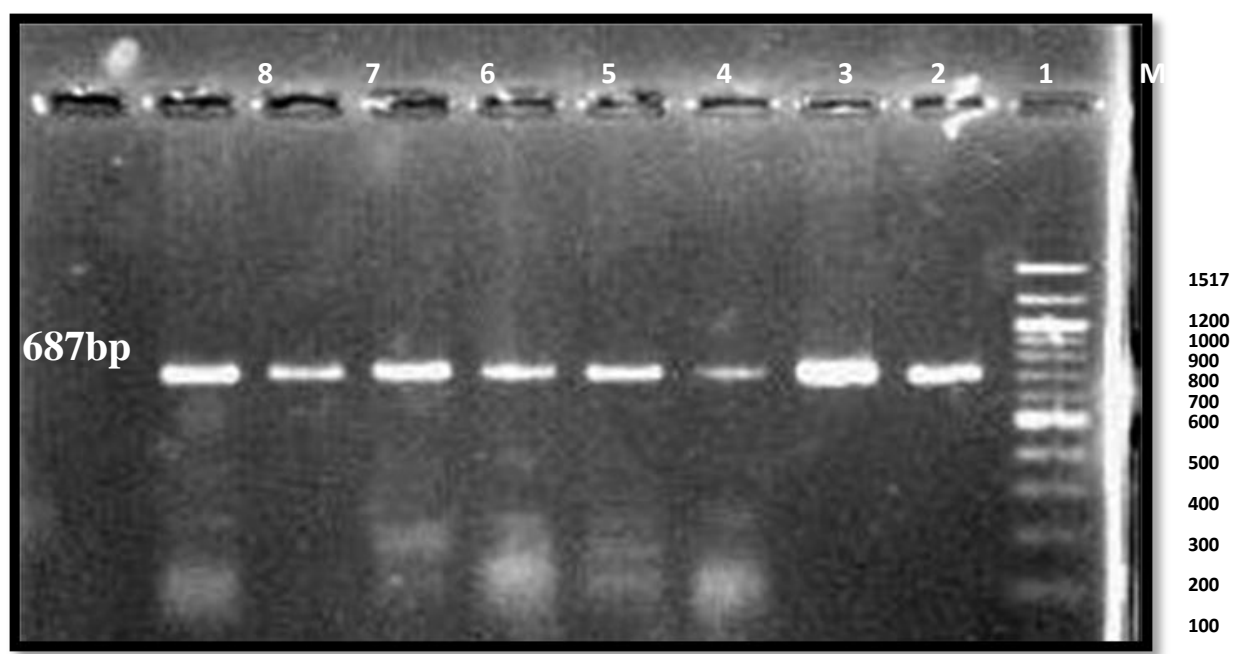

الصورة 6: نتائج تضاعف DNA لعزلات جرثومة A.baumannii باستخدام تقتية PCR لجين adeR

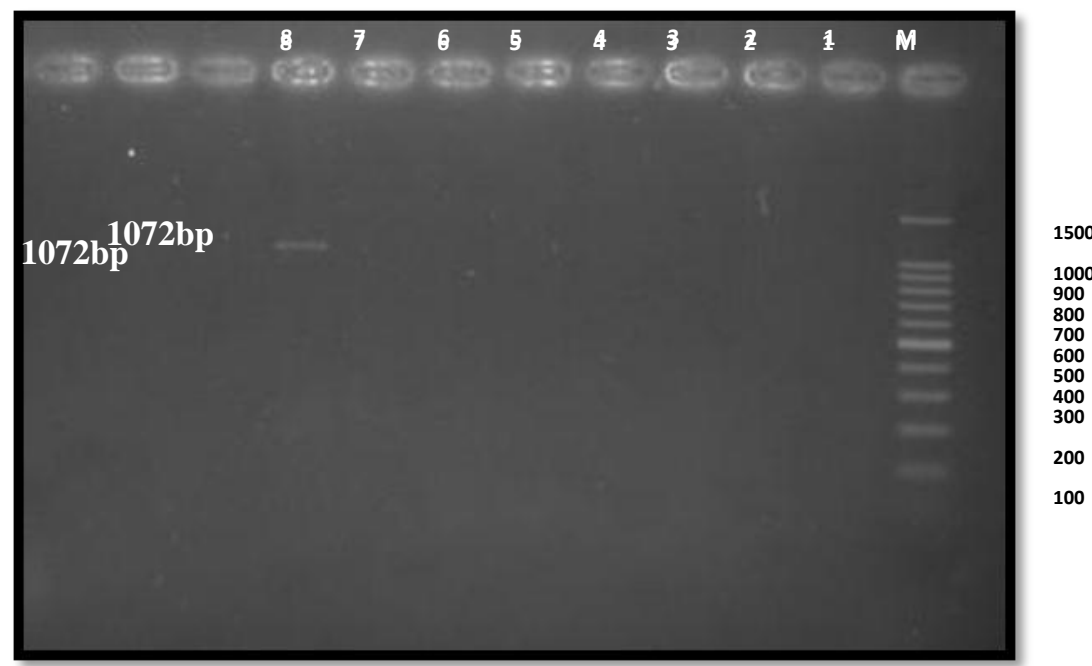

الصورة 7: نتائج تضاعف DNA لعزلات جرثومة A.baumannii باستخدام تقتية PCR لجين adeS 
لوحظ في (الجدول 4) أن تأثثر نظام الضخ adeABC في مقاومة الجرثومة لمضادات البيتالاكتام محدود، وان وجود

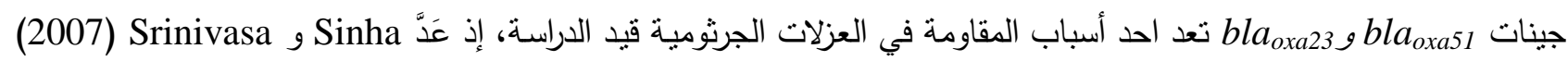

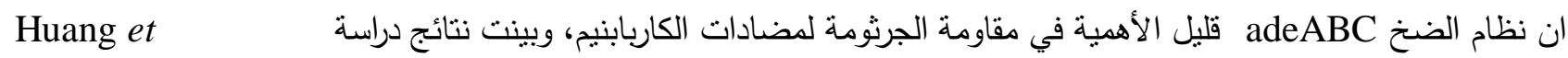

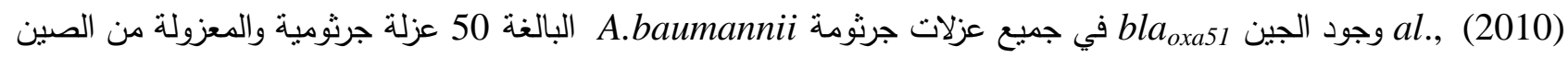
وذكر أن الجين bla oxa23 ينواجد في العزلات الجرثومية المقاومة لمضادات Carbapenems البالغة 22 عزلة جرثومية ولم تظهر الدراسة أية نسبة لوجود الجين bla oxa58 والجين bla oxa24 في جميع العزلات الجرثومية المتبقية على الرغم من امتلاك العزلات الجرثومية لجين adeB في العزلات الحساسة لـ Carbapenems. كما بين (الجدول 4) أن العزلات (3,2) و (7,6) تمنلكان الجينات نفسها، بينما كثفت مقارنة فحص الحساسية للمضادات الحيوية أنها تختلف في المقاومة وقد يعزى سبب ذلك لامتلاك العزلات الجرثومية على جينات أخرى تمكنها من مقاومة المضادات الحيوية (Chuang et al., 2011; Asadollahi et al., 2012). وبين (الجدول 4) احتواء جميع العزلات الجرثومية الثمانية على جين adeR وبنسبة بلغت (100\%)، وفيما يتعلق بالجين adeS العزلات الجرثوميـة الأخرى على الرغم من تطبيق اكثر من برنامج لتفاعل PCR، فضـلا عن ظهور كل من الجينيين AdeB

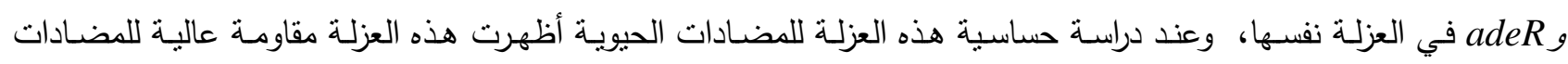

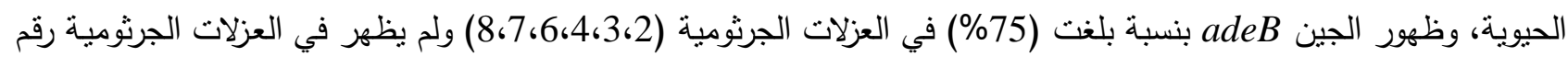

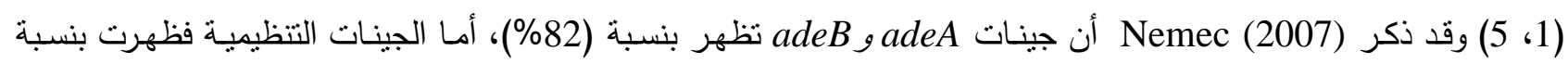
(A.baumannii (40) وفي العزلة الجرثومية ذب الرقم واحد فقد تبين عدم احتوائها على جين adeB وعند ملاحظة نتائج فحص الحساسية لهذه العزلة الجرثومية تبين انها كانت حساسة لمضادات الكلايكوسيدات الأمينية وحساسة للمضاد المباد الحيوي Tetracycillin بالإضـافة إلى عدم ظهور الجين التظظيمي adeS في هذه العزلة الجرثومية، وأظهرت العزلة ذي الرقم اثثين مقاومة عالية لجميع المضادات الحيوية المستخدمة على الرغم من عدم وجود الجين التتظيمي adeS في هذه العزلة، وربما

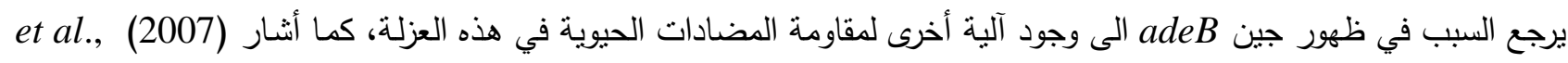

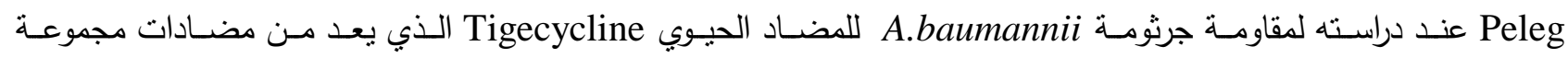

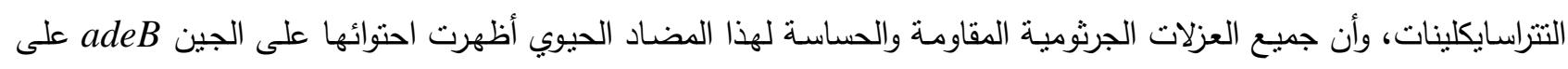
الرغم من عدم وجود طفرة في الجينات التنظيمية وزيادة التركيز المثبط الأدنى لهذا المضاد الحيوي، وتعبير جين adeB قد يشير

$$
\text { إلى وجود آلية أخرى لضخ المضاد الحيوي خارج الجرثومة. }
$$

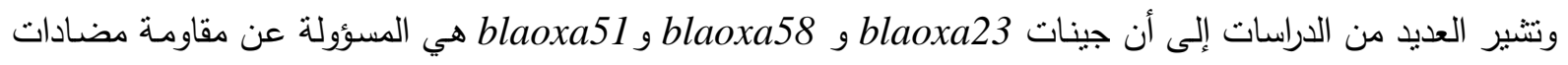
الكاربابنيم، كدراسة (2012) Sevillano et al., التي أجراها في مدينة بوليفيا وأنشار فيها إلى انتشار جين blaoxa58 بين

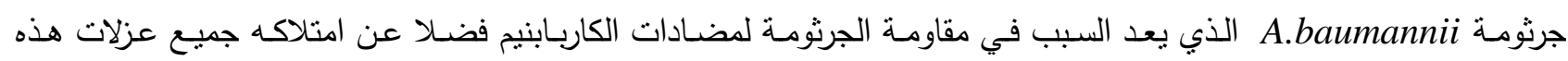
الجرثومة على الجين التشخيصي Lambiase et al., (2012) وأوضحت التي أجراها في إيطاليا أن جميع عزلات هذه الجرثومة المشخصة بجين blaoxa51 تمنلك الجين blaoxa58 في حين أن عدداً قليلاً منها فقط يمنلك الجين

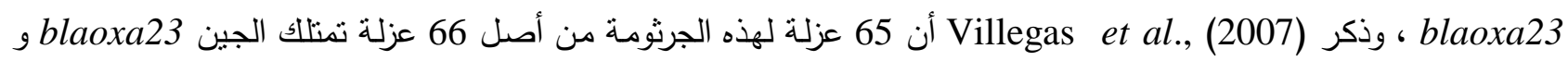
66 عزلة لهذه الجرثومة كانت حاوية للجين blaoxa51. 
أما دراسة (2013) Lopes et al., فقد كثفوا عن احتواء عدد كبير من عزلات جرثومة A.baumannii على الجين blaoxa51 الجين blaoxa58

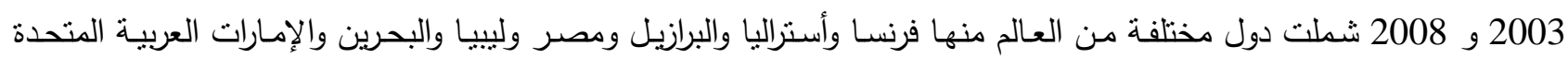
والجزائر وجنوب أفريقيا وفيتتام، نم فيها عزل جرثومة A.baumannii من المرضى في وحدة العناية المركزة في المستشفيات ومن

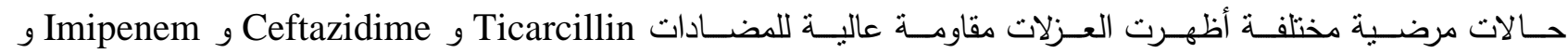
Meropenem وتوصل الباحثون إلى أن امتلاك الجرثومة لجين الـ blaoxa23 على الكروموسوم الجرثومي أو على البلازميد هو الذي يمنح الجرثومة مقاومة لهذه المضادات (2010, (Mugnier et al). في دراسة أخرى أجراها (2010) Lee et al., في إحدى المستشفيات في كوريا تم عزل هذه الجرثومة وكانت مقاومة

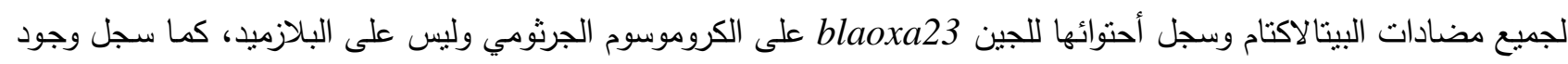
بعض السلالات المقاومة الفاقدة لهذا الجين وذكر ان سبب المقاومة يعود إلى امتلاكها لنوع آخر من الجينات التي تكسبها المقاومة لمضادات الكاربابنيم.

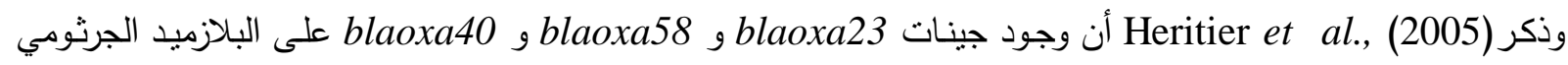

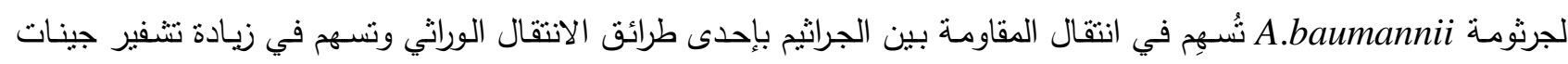

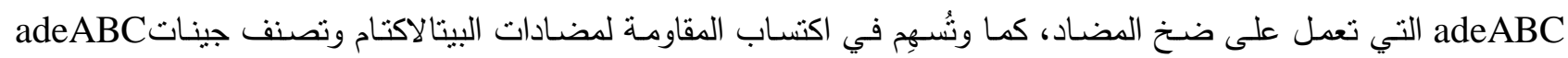
ضمن عائلة Resistance nodulation cell division التي تعد إحدى خمس عوائل لضخخ المضادات الحيوية

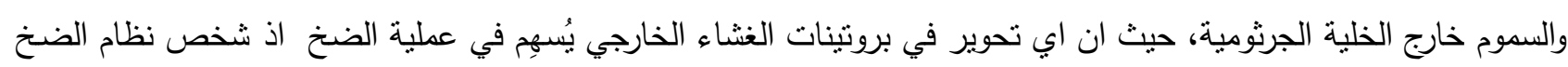
adeABC في جرثومة A.baumannii المتعددة المقاومة للمضادات الحيوية في عام 2001 حيث تقع جينات adeABC على فئى

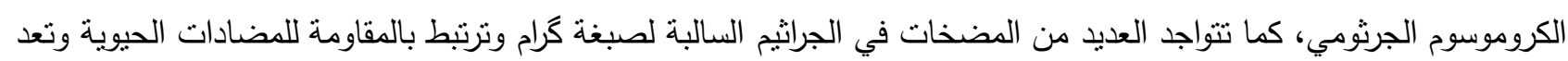

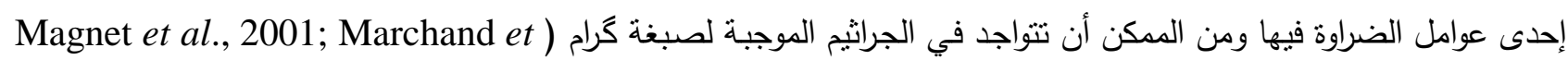
.(al., 2004

وركزت دراسة Nemec et al., (2007) في العلاقة بين حساسية المضاد الحيوي Netilmicin مع نظام ضـخ المضاد الحيوي adeABC، إذ اتضح أن العزلات التي كانت حساسة لهذا المضاد الحيوي كانت سالبة لظهور واحد أو أكثر من الجينات، ووجد ان (0.9\%) من العزلات الجرثومية كانت موجبة لجينات adeA و adeB و adeC وسالبة لظهور جين adeS و و ade

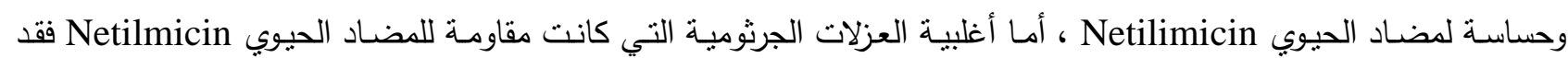
كانت تحمل جينات adeA و adeS و adeB و كما أنشار إلى أن 91\% من السلالات تحتوي في الأقل واحداً من الجينات الخمسة (adeA, adeB, adeC, adeS, adeR).

\section{المصادر العربية}

السليم، سحر لقمان؛ شريف، أديبة يونس (2018). التحري عن انزيمات بيتالاكتاميز المعدنية (نوع IMP) في بعض أنواع الجراثيم

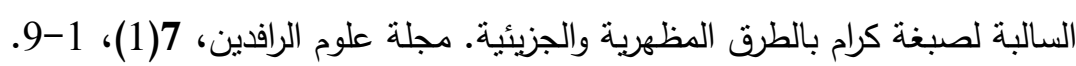

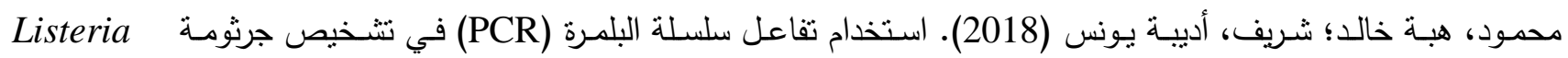
monocytogenes 
Adams, M.P.; Koch, R.W. (2010). "Pharmacology Connections to Nursing Practice". Pearson. U.S.A. pp. 787-843

Asadollahi, P.; Akbari, M.; Soroush, S.; Taherikalani, M.; Asadollahi, K.; Sayehmiri, K.; Maleki, A.; Maleki, M.H.; Karimi, P.; Emaneini, M. (2012). Antimicrobial resistance patterns and their encoding genes among Acinetobacter baumannii strains isolated from burned patients. Elsevier, 1-6.

Chuang, Y.C.; Sheng, W.H.; Li, S.Y.; Lin, Y.C.; Wang, J.T.; Chen, Y.C.; Chang, S.C. (2011). Influence of Genospecies of Acinetobacter baumannii complex on clinical outcomes of patients with Acinetobacter Bacteremia. Clin. Infect Diseases .52(3), 352-360.

Coyne, S.; Guigon, G.; Courvalin, P.; Perichon, B. (2010). Screening and quantification of the expression of antibiotic resistance genes in Acinetobacter baumannii with a microarray. Antimicrobial Agents and Chemotherapy. 54(1), 333-340.

Eswaran, J.; Koronakis, E.; Higgins, M.K.; Hughes, C.; Koronakis, V. (2004). Three`s company: component structures bring a closer view of tripartite drug efflux pumps. Curr. Opin. Struct. Biol. 14(6),741-747.

Heritier, C.; Poirel, L.; Lambert, T.; Nordmann, P. (2005). Contribution of acquired CarbapenemHydrolyzing Oxacillinases to carbapenem resistance in Acinetobacter baumannii. Antimicrobial Agents and Chemotherapy. 49(8), 3198-3202.

Huang, J.; Huang, J.; Yu, F.; Wang, X.; Li, G. (2010). AdeABC efflux pump: less important role in Acinetobacter baumannii against carbapenems. African J. Microbiol Res. 4(20), 2148-2152.

Huys, G.; Cnockaert, M.; Nemec, A.; Swings, J. (2005). Sequence-based typing of adeB as a potential tool to identify intraspecific groups among clinical strains of multidrug-resistant Acinetobacter baumannii. J. Clin. Microbio. 43(10), 5327-5331.

Lambiase, A.; Piazza, O.; Rossano, F.; Pezzo, M.D.; Tufano, R.; Catania, M.R. (2012). Persistence of carbapenem - resistant Acinetobacter baumannii strains in an Italian intensive care unit during a forty-six month study period. New Microbiology. 35, 199-206.

Lee, K.; Lee, M.A.; Lee, C.H.; Lee, J.; Roh, K.H.; Kim, S.; Kim, J.J.; Koh, E.; Youg, D.; Chong,Y.; The KONSAR group. (2010). Increase of Ceftrazidime and Fluoroquinolone - resistant Klebsilla pneumoniae and Imipenem -resistant Acinetobacter spp. in Korea: analysis of KONSAR study Data from 2005 and 2007. Yonsei Med J. 51(6), 901- 911.

Lopes, B.S.; Gallego, L.; Amyes, S.G.B. (2013). Multi-drug resistance profiles and the genetic features of Acinetobacter baumannii isolates from Bolivia. J. Infect. Dev. Ctries. 7(4), 323328.

Maragakis, L.L.; Perl, T.M. (2008). Acinetobacter baumannii: epidemiology, antimicrobial resistance, and treatment options. Antimicrobial Resistance. 46, 1254-1263.

Magnet, S.; Courvalin, P.; Lambert, T. (2001). Resistance-Nodulation-Cell division-type efflux pump involved in aminoglycoside resistance in Acinetobacter baumannii Strain BM4454. Antimicrobial agent and Chemotherapy. 45(12), 3375-3380.

Mahon, C.R.; lehmen, D.C.; Manuseis, G. (2011). "Diagnostic Microbiology". $4^{\text {th }}$ ed. Saunders Elsevier. USA . pp.1-931.

Marchand, I.; Damier-Piolle, L.; Courvalin, P.; Lambert, T. (2004). Expression of the RND-Type efflux pump AdeABC in Acinetobacter baumannii is regulated by the AdeRS twocomponent system. Antimicrobial Agent and Chemotherapy. 48(9), 3298-3304.

Mims, C.; Dockrell, H.M.; Goering, R.V.; Roitt, I.; Wakelin, D.; Zuckerman, M. (2004). "Medical Microbiology". $3^{\text {rd }}$ ed. Elsevier mosby. United Kingdom.

Mugnier, P.D.; Poirel, L.; Naas, T.; Nordmann, P. (2010). Worldwide dissemination of the bla ${ }_{O X A-23}$ carbapenemase gene of Acinetobacter baumannii. Emerging Infect Diseases.16(1), 35-40. 
Nemec, A.; Maixnerova, M.; Reijden, T.J.K.V.D.; Broek, P.J.V.D.; Dijkshoorn, L. (2007). Relationship between the AdeABC efflux system gene content, netilmicin susceptibility and multidrug resistance in a genotypically diverse collection of Acinetobacter baumannii strains. J. Antimicrob Chemother. 26(60), 483-489.

Nowak, P.; Paluchowska, P.; Budak, A. (2012). Distribution of bla ${ }_{O X A}$ genes among carbapenemresistant Acinetobacter baumannii nosocomial strains in Poland. New Microbiol. 35, 317325.

Ozen, N.; Ergani, A.; Naas, T.; Ogunç, D.; Gultekin, M.; Colak, D.; Nordmann, P. (2009). Outbreak of Carbapenem-resistant Acinetobacter baumannii producing the carbapenemase OXA-58 in Turkey. The Open Antimicrobial Agents J.,1, 1-8.

Paulsen, I.T. (2003). Multidrug efflux pumps and resistance: regulation and evolution. Curr. Opin. Microbiol. 6(5), 446-451.

Peleg, A.Y.; Adams, J.; Paterson, D.L. (2007). Tigecycline efflux as a mechanism for nonsusceptibility in Acinetobacter baumannii. Antimicrobial Agents and Chemotherapy. 51(6), 2065-2069.

Poirel, L.; Marque, S.; Heritier, C.; Segonds, C.; Chabanon, G.; Nordmann, P. (2005). OXA-58, a Novel Class D-B-Lactamase involved in resistance to carbapenems in Acinetobacter baumannii. Antimicrobial Agents and Chemotherapy. 49(1), 202-208.

Pommerville, J.C. (2011). "Alcamo's Fundamentals of Microbiology". $9^{\text {th }}$ ed. Jones and Bartlett publishers. USA.

Sevillano, E.; Fernandez, E.; Bustamante, Z.; Zabalaga, S.; Rosales, I.; Umaran, A.; Gallego, 1. (2012). Emergence and clonal dissemination of carbapenem-hydrolysing OXA-58 producing Acinetobacter baumannii isolates in Bolivia. J. Med. Microbio. 61, 80-84.

Sinha, M.; Srinivasa, H. (2007). Mechanisms of resistance to carbapenems in meropenem resistant Acinetobacter isolates from clinical samples. Official Publication of Indian Association of Medical Microbiologists. 25(2), 121-125.

Srinivasan, V.B.; Rajamohan, G.; Pancholi, P.; Stevenson, K.; Tadesse, D.; Patchanee, P.; Marcon, M.; Gebreyes, W.A. (2009). Genetic relatedness and molecular characterization of multidrug resistant Acinetobacter baumannii isolated in central Ohio, USA. Bio. Med. Central. 8(21), 1-10.

Sun, J.R.; Perng, C.L.; Chan, M.C.; Morita, Y.; Lin, J.C.; Su, C.M.; Wang, W.Y.; Chang, T.Y.; Chiueh, T.S. (2012). A Truncated AdeS kinase protein generated by ISAba1 insertion correlates with tigecycline resistance in Acinetobacter baumannii. PLOS one Biology. 7(11), $1-14$.

Villegas, M.V.; Kattan, J.N.; Correa, A.; Lolans, K.; Guzman, A.M.; Woodford, N.; Livermore, D.; Quinn, J.P. (2007). The Colombian nosocomial bacterial resistance Study Group. Antimicrobial Agents and Chemotherapy., 51(6), 2001-2004.

Wieczorek, P.; Sacha, P.; Hauschild, T.; Zorawski, M.; Krawczyk, M.; Tryniszewska, E. (2008). Multidrug resistant Acinetobacter baumannii - the role of AdeABC (RND family) efflux pump in resistance to antibiotics. Folia. Histochem. Cytobiol. 46(3), 257-267.

Zhang, Y.; Li, Z.; He, X.; Ding, F.; Wu, W.; Luo, Y.; Fan, B.; Cao, H. (2018). Overproduction of efflux pumps caused reduced susceptibility to carbapenem under consecutive imipenemselected stress in Acinetobacter baumannii. J. Infection and Drug Resistance. 29(11), 457467. 